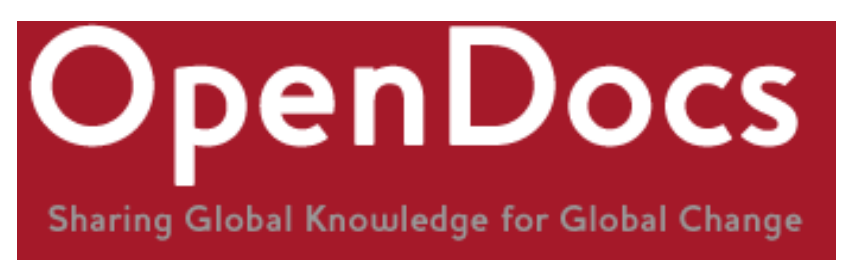

Title: Initiatives of tropical agroforestry to sustainable agriculture: A case study of Capasia Village, Northern Bangladesh.

Citation: Rahman, S.A., Paras, F.D., Khan, S.R., Imtiaj, A., Farhana, K.M., Toy, M.M., Akhand, M.B. andSunderland, T.C.H. (2011) Initiatives of tropical agroforestry to sustainable agriculture: A case study of Capasia Village, Northern Bangladesh. Journal of Horticulture and Forestry, vol. 3, no. 4, pp. 115-121.

Official URL: http://www.academicjournals.org/journal/JHF/article-abstract/D47C7C21229

More details/abstract: A relatively large percentage of the population in Bangladesh lives under the poverty line and is affected by the country's degrading natural resources. Agroforestry has been seen as one of the few options to lift people out of poverty. Research into the costs and benefits of agroforestry was undertaken in Capasia Village in Northern Bangladesh. Initial results indicate that agroforestry may not only be an optimal livelihood solution for poor farmers, biodiversity conservation and environmental sustainability but agroforestry systems also provide good economic rates of return. Thus the farmers who engage in agroforestry are benefited in different ways.

Version: Published version.

Terms of use: This journal provides immediate open access to its contents to encourage the global exchange of knowledge. Authors retain copyright and grant the journal right of first publication with the work simultaneously licensed under a Creative Commons License that allows others to share the work with an acknowledgement of the work's authorship and initial publication in this journal. Authors are able to enter into separate, additional contractual arrangements for the non-exclusive distribution of the journal's published version of the work (e.g., post it to an institutional repository or publish it in a book), with an acknowledgement of its initial publication in this journal.

This is a download from OpenDocs at the Institute of Development Studies

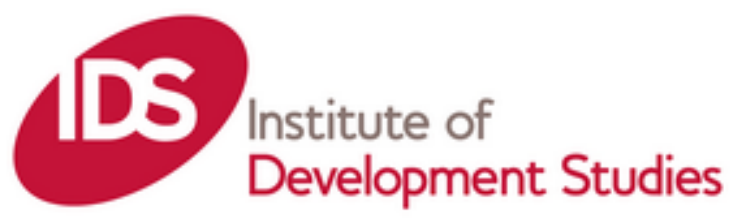




\title{
Initiatives of tropical agroforestry to sustainable agriculture: A case study of Capasia Village, Northern Bangladesh
}

\author{
S. A. Rahman ${ }^{1 \star}$, F. D. Paras $^{2}$, S. R. Khan ${ }^{3}$, A. Imtiaj ${ }^{4}$, K. M. Farhana ${ }^{5}$, M. M. Toy ${ }^{6}$, M. B. Akhand ${ }^{7}$ \\ and T. Sunderland ${ }^{1}$ \\ ${ }^{1}$ Center for International Forestry Research (CIFOR), Bogor Barat 16680, Indonesia. \\ ${ }^{2}$ Department of Social Forestry and Forest Governance, College of Forestry and Natural Resources, \\ University of the Philippines, Los Banos, Philippines. \\ ${ }^{3}$ Natural Resources Institute, University of Manitoba, Canada. \\ ${ }^{4}$ Department of Botany, University of Rajshahi, Rajshahi, Bangladesh. \\ ${ }^{5}$ Department of Sociology, University of Padova, Italy. \\ ${ }^{6}$ Shanto-Mariam University of Creative Technology, Dhaka, Bangladesh. \\ ${ }^{7}$ Intervida (Bangladesh Country office), Dhaka, Bangladesh.
}

Accepted 8 February, 2011

\begin{abstract}
A relatively large percentage of the population in Bangladesh lives under the poverty line and is affected by the country's degrading natural resources. Agroforestry has been seen as one of the few options to lift people out of poverty. Research into the costs and benefits of agroforestry was undertaken in Capasia Village in Northern Bangladesh. Initial results indicate that agroforestry may not only be an optimal livelihood solution for poor farmers, biodiversity conservation and environmental sustainability but agroforestry systems also provide good economic rates of return. Thus the farmers who engage in agroforestry are benefited in different ways.
\end{abstract}

Key words: Agroforestry, poverty, farmers, livelihoods, conservation.

\section{INTRODUCTION}

At present in Bangladesh, many environmental problems stem from poverty- often contributing to a downward spiral in which poverty exacerbates environmental degradation and environmental degradation exacerbates poverty (ADB, 2004, 2001). In poor rural areas, for example, there are close links between the lack of family planning, concomitant population growth and extensive deforestation, as local farmers fell tropical forests for firewood and new farmland. Forests are depleted by commercial timber exploitation and gradually converted into pastures, plantations and cultivated fields (Rahman et al., 2007). Recycling periods for slash-and-burn cultivation systems declined from about 20 years in 1900 to about three years in the recent decade, eliminating forest fallows. According to the World Development

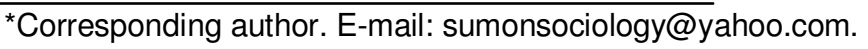

Report (World Bank, 2000), only 5.6\% of the total area of Bangladesh is forested and that area is being depleted at the alarming rate of $3.1 \%$ per annum (FAO, 2009). Moreover, due to the loss of firewood resources, rural communities turn to alternative fuels such as cow dung and crop residues that previously served as organic manure on agricultural fields. The shorter fallow periods, reduced organic inputs and repeated removal of nutrients with harvested crops have contributed to soil degradation and consequently, lowered crop yields and farmers' returns leading to more poverty (Rahman et al., 2008, 2007).

Agroforestry is a collective name for land use systems and practices where woody perennials are deliberatly integrated with crops and/or animals on the same land management unit. The integration can either be in a spatial mixture or in temporal sequence. There are normally both ecological and economic interactions between the woody and the non-woody components in 
Table 1. Site characteristics.

\begin{tabular}{ll}
\hline Characteristics & Description \\
\hline Property zoning & Agriculture \\
Existing agroforestry species & Mango, coconut, paddy and wheat \\
Access & National highway \\
Topography & Flood plain \\
Slop & $0-5 \%$ \\
Elevation & $40 f t$. \\
Rainfall & Over 1450 per year \\
Average tempareture & Summer 37.8, Winter 9.2 \\
Dry season & December- March \\
Soil condition & Loamy \\
Water resources & Ponds, mainly natural rainfall \\
\hline
\end{tabular}

agroforestry. For centuries, agroforestry has been practiced around the world and is most commonly associated with tropical and sub-tropical regions. Agroforestry can provide many different environmental and production benefits for a farm and its surrounding area. Nair (1989) defines agroforestry as a sustainable land management system which increases the overall yield of the land, combines the production of crops (including tree crops) and forest plants and /or animal simultaneously or sequentially, on the same unit of land, and applies management practices that are computable with the cultural practices of the local population.

In Bangladesh, agroforestry has been practised in different areas for a relatively long time. However, formal agroforestry policies were officially initiated only in 1977 to 1978 (Alim, 1980). Agricultural cropping systems grown with in association with planted tree species were found to be successful in various parts of Bangladesh and agroforestry is seen as one of the very few livelihood options to lift people out of poverty (Table 1).

\section{MATERIALS AND METHODS}

The research methods were applied primarily and they include:

(1) A survey and rapid rural appraisal (RRA) for the basic social circumstances of the villages.

(2) Short structured interviews with a purposive sample of 110 households focused primarily towards experiences and actual and envisaged costs and benefits of agroforestry.

(3) Participatory rural appraisal (PRA) and field-based surveys implemented by the 60 interviewees.

Other data was gathered by way of interviews with key informants (GO, NGO, firms and PO) and market prospecting. Moreover, secondary data gathered from local and overseas resources and Internet. 'Kapasia' village of Rajshahi District in North Bangladesh were selected purposively. The village was selected based on various criteria. Firstly, there is an ongoing agroforestry programme in the area and local people have experience with agroforestry practices. Secondly, the researchers are familiar with the culture, norms and local language of the study area and have undertaken previous research in the area.

\section{RESULTS AND DISCUSSION}

\section{Financial analysis of agroforestry}

Research data indicates that agroforestry provides substantially more benefits than traditional agricultural systems. The analysis of collected data is to estimate the value of net returns from agroforestry. Actual costs and benefits vary widely depending on local conditions, however, for the purposes of our analysis, all values are based on early 2010 prices.

\section{Major costs of initiating agroforestry projects}

Establishment cost: The establishment cost involves land preparation, seedlings, planting etc., for agroforestry activities. Costs for preparation vary greatly depending on the condition of the site. The farmers of the study area purchased seedlings from private or state sources, and range in price is dependent on species and quantity grown. The average establishment cost is not more than Tk. 15000 per acre. Usually land costs are not included in the projected costs of agroforestry projects as it is assumed that landowner already has secure tenure rights (Table 2).

Pesticides and fertilizer: Pesticides and fertilizer are often used to enhance the trees and crops in early years. After three to five years fertilizer is used often as tree species provide nutrients for understory crops. Usually the pesticides and fertilizer costs are Tk. 3000 per acre in the early stage of the project (Table 2). 
Table 2. Some costs in agroforestry project.

\begin{tabular}{lccc}
\hline Operation & Year & Comments & Approximate cost (Tk.) \\
\hline Establishment coast & 0 & --- & 9000 per acre \\
Pesticides and fertilizer & $0-4$ & --- & 3000 per acre \\
& 2 & Form pruning & Only self labor \\
Pruning and thinning & 4 & pruning 0-2 m & \\
& 5 & pruning $2-4 \mathrm{~m}$ & \\
Labor cost & 6 & pruning $4-6 \mathrm{~m}$ & 1500 per acre \\
\hline
\end{tabular}

USD $1=69.72$ Tk as of September 2010 .

Table 3. Net cash flow (Tk.) of agroforestry project per acre (depicted in line graph above).

\begin{tabular}{lccccccccccc}
\hline Year & $\mathbf{1}$ & $\mathbf{2}$ & $\mathbf{3}$ & $\mathbf{4}$ & $\mathbf{5}$ & $\mathbf{6}$ & $\mathbf{7}$ & $\mathbf{8}$ & $\mathbf{9}$ & $\mathbf{1 0}$ & $\mathbf{1 1}$ \\
\hline Cost & 19020 & 5040 & 5040 & 5040 & 4800 & 4800 & 4800 & 4800 & 4680 & 4920 & 4920 \\
Returns & 30000 & 30000 & 30000 & 30600 & 31900 & 32520 & 33000 & 40080 & 48000 & 48000 & 51120 \\
Net & 10980 & 24960 & 24960 & 25560 & 27100 & 27720 & 28200 & 35280 & 43320 & 43080 & 46200 \\
\hline
\end{tabular}

Pruning and thinning: Pruning and thinning is used to improve the form of trees by removing lower branches or multiple stems in order to optimize timber production and quality and quantity of fruits (Table 2).

Labor cost: Farmers hire labor when it is needed, especially during the harvesting period. An average reasonable labor cost is seen Tk. 60 per day for hired labor. At other times of the year farmers rely on their own labor or that of a family member. For the analysis, it is important to calculate the amount of labor required on a yearly basis in order to give meaningful result. The yearly hired labor cost Tk. 1,500, which represents a maximum 10 to 15 days (Table 2 ).

\section{Returns from agroforestry}

The farmers realized relatively early crop yields from agroforestry in Capasia village (the first 1 to 3 years). However, from 4th year they also earned fruits from tree crops. In such systems it is seen that, from 4th year, the yields of tree crops are increasingly high. Research data indicates in the beginning year the farmers earned average Tk. 10,980 per acre from agroforestry. They earned Tk. 24,960; Tk. 24,960, Tk. 25,560, Tk. 27,100 and Tk. 27,720 from the year of $2 \mathrm{nd}, 3 \mathrm{rd}, 4$ th, 5 th and 6th respectively (Table 3 ). The net income is gradually increased from this project (Graph 1).

The mango (Mangifera indica) and coconut (Cocos nucifera) are the most commonly planted agroforestry tree species. The wood of the mango tree is used in furniture and for construction and the leaves and bark are used medicinally and are also used as an energy source of cooking and for animal feed. The ripe fruit is eaten raw and can be used to make jam, chutney, deserts, and is sold locally as a major source of income. The juice, puree, and ripe and green fruit are often exported to some other countries. The mango is also an important Hindu religious plant, and its leaves are used in religious ceremonies.

The brown nut of coconut is a major human staple and animal food. The husk can be dried and made into copra, which is an important source of income. Juice from the immature green nut is an important drink and source of safe drinking water in dry areas and in times of drought. The sap from the flower stalk is used to make fresh and fermented toddy. The timber is used for many purposes. The trunk, fronds, shells, and husks are a major source of fuel for cooking. The roots are used for making fish traps, and the husk fiber is used to make cord, that is used for lashing house beams and other purpose. The shell is used to make containers, fishhooks, charcoal and other useful items. The leaves and fronds are used for weaving baskets, hats, fans, floor mats, food containers, roofing, as well as for shade and mulching in taro gardens. The midrib leaflets are used in brooms, as a toothpick and for other purposes. Almost all parts of the tree are used medicinally. Coconut is a plant of spiritual and ritual importance in many areas.

The returns earned from agroforestry provide farmers the means to enrich their economic and social status in the village. For example, the additional income they 


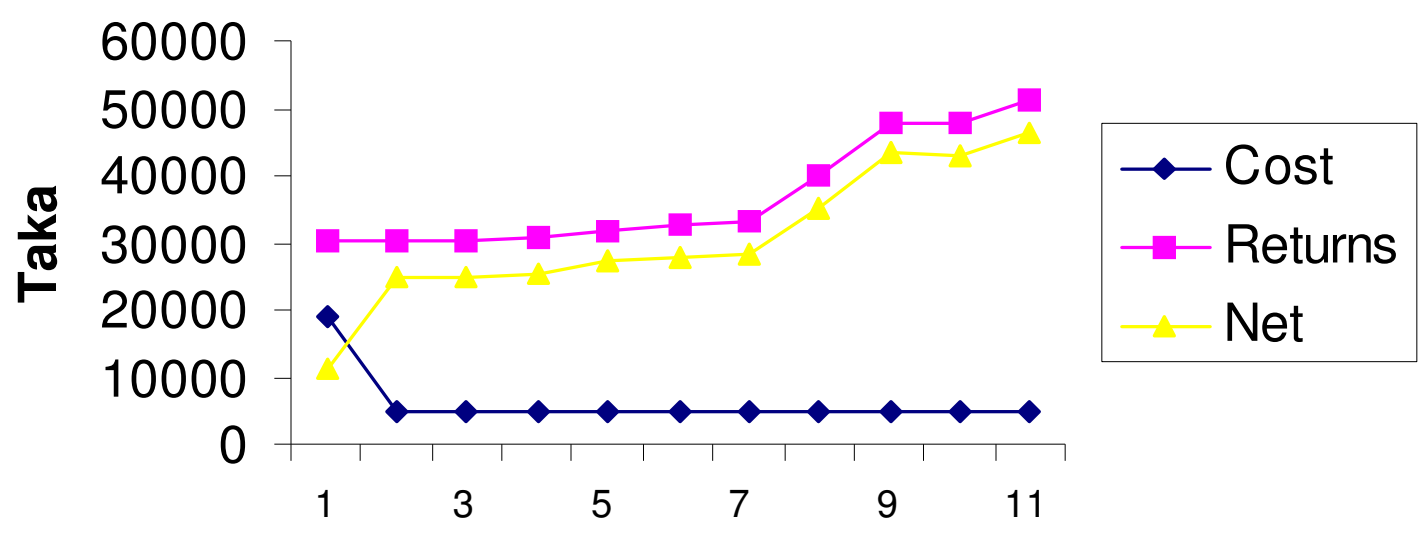

\section{Year}

Graph 1. Net cash flow of agroforestry project per acre.

Table 4. Agroforestry systems make more efficient use of natural resources.

\begin{tabular}{ll}
\hline Soil nutrients & $\begin{array}{l}\text { Trees promote nutrients cycling and efficient use; nutrient status is increased through } \\
\text { nitrogen fixation and the uptake of deep soil nutrients. }\end{array}$ \\
Sun & Multistoried cropping systems intercept and use sunlight at all level. \\
Water & $\begin{array}{l}\text { Tress can increase water availability in the soil by reducing runoff and evapotranspiration, } \\
\text { while increasing water infiltration and soil water-holding capacity. }\end{array}$ \\
\hline
\end{tabular}

realize is used for mainly as food, clothes, education and health.

Owners of agroforestry projects in study area are also capture the indirect benefits of forestry such as shade, erosion control, wildlife habitat, aesthetics, land values, etc. However it is difficult to place an exact dollar figure on these additional ecosystem services.

The costs and benefits of agroforestry in the study area vary widely, and depend upon site conditions as well as on many factors such as tree spacing, maintenance techniques, and the rate of growth of trees. To compare an agroforestry project with agriculture, the same analysis should be undertaken for both. Below is the comparable financial viability of two options such as agroforestry and agriculture:

1. Agriculture may not be as profitable, but the returns are annual. Agroforestry has a relatively large cost early in the project, with positive returns occurring many years in the future.

2. Agricultural markets are relatively well known in the short term. Agroforestry markets are more uncertain due to the relatively long time horizon.

3. Most farmers have the skills and confidence for agricultural production. New skills and technologies may have to be learned and understood to successfully carry out a commercial agroforestry product.

\section{Role of agroforestry}

Population growth, increasing economic needs, environmental degradation, and a shortage of arable land make the development of sustainable and efficient agricultural systems crucial. Agroforestry practices can improve productivity and reduce inputs, while mitigating some of the environmental damage cause by the past processes of deforestation and the removal of trees from the landscape (Tables 4 to 9).

\section{Improved economic benefits}

It is more likely that agroforestry can provide improved economic benefits to landowners. Aside from improving the value of the timber products, there are also a number of strategies that can improve the overall returns from agroforestry. Because of closer landowner involvement, small-scale forestry is uniquely suited to incorporate nontimber yields, which can increase the economic 
Table 5. Agroforestry systems provide a more favorable environment for sustained production.

\begin{tabular}{ll}
\hline Shade & $\begin{array}{l}\text { Filtered shade conserves water, produces evapotranspiration, keeps topsoil cool, and } \\
\text { helps maintain beneficial microbial activity }\end{array}$ \\
Wind protection & Trees protect crops from wind damage and soil from wind erosion and drying. \\
Soil conservation & $\begin{array}{l}\text { Tree root and mycorrhizal systems reduce nutrient leaching, bind soil, and prevent } \\
\text { erosion. Tree leaf litter enhances soil physical, chemical, and biological conditions, } \\
\text { which makes soil more resistant to erosion and more able to absorb and hold water. }\end{array}$ \\
Nutrient cycling & $\begin{array}{l}\text { Through nitrogen- fixing trees and nutrient uptake from deep soil layers, trees promote } \\
\text { more closed nutrient cycling and more efficient use of nutrients. }\end{array}$ \\
Habitat diversity & $\begin{array}{l}\text { Trees provide habitats for birds, insects, and other animals that help maintain pest/ } \\
\text { predator balance in the system. }\end{array}$ \\
\hline
\end{tabular}

Table 6. Agroforestry systems can be more profitable.

\begin{tabular}{ll}
\hline Reduce expenses & $\begin{array}{l}\text { Through nutrient cycling and soil and water conservation, tree reduce the need to purchase } \\
\text { fertilizer and water. Trees may also reduce the need for pesticides by providing habitat for } \\
\text { pest predators. }\end{array}$ \\
Diversified products & $\begin{array}{l}\text { Mixed cropping systems typically have two or more economic products, reducing } \\
\text { dependence on market conditions for a single crop. }\end{array}$ \\
$\begin{array}{l}\text { Continuous flow of } \\
\text { product }\end{array}$ & $\begin{array}{l}\text { Agroforestry systems often combine short term and long term crops, which can lead to a } \\
\text { high level of total productivity and year round production. }\end{array}$ \\
Greater self reliance & $\begin{array}{l}\text { Agroforestry can reduce farmer's dependence on purchased products and resources, as } \\
\text { well as reducing vulnerability to changing market conditions. }\end{array}$ \\
\hline
\end{tabular}

benefits. The nontimber crops may include short-term crops that are phased out as the forest matures, or permanent production systems of crops, animals, and/or multiple use plants that provide sustained yields for many years.

Earlier returns: An advantage of agroforestry is the possibility of early yields from non timber crops such as herbs, medicinal, fruits, or other crops that are interplanted with the timber trees. By producing economic returns early in the project, non-timber yields can pay back investment costs earlier than timber yields, which can enhance the economics of the participating household as a whole.

More efficient use of space: In non-agroforestry plantings, the space between trees must be mowed or maintained, which is a considerable expense. Using that space for a crop instead may take a similar amount of effort to maintain, but will also provide a return.

Added ecosystem diversity: Generally, the more species included in a system, the lower the risk of devastating problems caused by pests and disease infestations.

Added economic flexibility: Multiple products give the landowner the option to sell products that will give the best overall return in a given year. Product lines can change from year to year based on demand and market conditions.

Short-term non-timber yields (Sequential cropping systems): While forest seedlings are still small, there is considerable open space between them that can be used to grow short-term agricultural crops. By growing such crops during the first 2 to 4 years, the cost of weed control and other maintenance for the forest seedlings can be reduced. Income from these crops can help to offset part of the establishment costs. This is called "sequential planting", a practice wherein short-term crops are planted with, and eventually replaced by, long term trees. Sequential planting can be a viable system for farmers or forest planters who need a short term return as they invest in long term tree crops (Table 9).

Many combinations of crops and trees have been 
Table 7. Agroforestry systems can improve the environment.

\begin{tabular}{ll}
\hline $\begin{array}{l}\text { Reduced pressure on natural } \\
\text { forests }\end{array}$ & $\begin{array}{l}\text { On-farm production of wood and other forest products reduce pressure to exploit } \\
\text { natural forests. }\end{array}$ \\
Species diversity & $\begin{array}{l}\text { Trees and mixed systems provide habitat and support biodiversity (wildlife, micro } \\
\text { life, etc.) }\end{array}$ \\
Resource conservation & Trees can improve conservation of soil, nutrients, and water in the landscape. \\
Carbon sequestration & $\begin{array}{l}\text { Trees store carbon from the air, helping to reduce carbon dioxide pollution and } \\
\text { global climate change. }\end{array}$ \\
Decreased pollution & $\begin{array}{l}\text { Nutrient cycling of trees may reduce the use of chemical fertilizers, thus reducing } \\
\text { chemical and soil run-off. }\end{array}$ \\
\hline
\end{tabular}

Table 8. Agroforestry systems are culturally compatible.

\begin{tabular}{ll}
\hline Locally based & $\begin{array}{l}\text { Agroforestry systems incorporate species and techniques that have been used traditionally } \\
\text { in local areas for many generations, in some cases in thousands of years. }\end{array}$ \\
Adaptable & $\begin{array}{l}\text { Due to timber experience and acceptance over many decades, traditional systems and } \\
\text { species provide a strong, locally based framework for future agroforestry development. }\end{array}$ \\
Acceotable & $\begin{array}{l}\text { By combining production with conservation and land improvement, the agroforestry } \\
\text { approach can increase the acceptability and adoption of sustainable practices. }\end{array}$ \\
\hline
\end{tabular}

Table 9. Generic sequential cropping system.

\begin{tabular}{ll}
\hline Early stage & Initial planting of tree seedlings and crops. \\
Years 1-5 & Trees grow and begin to shade out crops. \\
Years 6+ & Trees close canopy, crops are removed. \\
\hline
\end{tabular}

combined in this kind of system, with crops including rice, rice corn, beans, root crops, vegetables, fruits, ornamental flowers or foliage, and other cash or subsistence crops. There are several advantages to sequential plantings in agroforestry, including:

1. Greater efficiency in land use (less land area is fallow while tree crops mature).

2. Increased efficiency in labor (because crop maintenance can overlap).

3. Increased total yields.

4. Long term investment made more economically viable through short-term yields.

Sustained non-timber yields: While sequential crops are phased out as the forest matures, there are a number of agroforestry practices that are permanent components of the forestry system. These include shade-loving crops grown under the forest trees, animal integrated with the forest trees, or non-timber products such as fruit and seeds. These supplementary products can provide sustained sources of income for many years over the life of the project. Unlike sequential cropping, many of these systems have fewer forestry trees per acre, and therefore lower timber yields, than a pure stand of forestry trees. However, the earlier, sustained yields from non-timber products make this practice economically attractive to many landowners. In addition, landowners who integrate long-term non-timber yields with their forestry planting have the advantage of a diversified cropping system, which lowers the risk of total loss in the event of environmental or market conditions that may affect a single kind of crop.

Understory crops: Understory crops are grown in the shady environment under the timber trees. Unlike sequential crops, understory crops are installed and managed to produce for many years as the forest matures. Usually the number of timber trees per acre is 25 to $27 \%$ less than when timber trees are planted alone, 
to make space for the understory crops. There are many valuable cash and subsistence crops that thrive in the shady climate under trees. Planting that takes advantage of the understory range from simple systems consisting of one species in the overstory and one in the understory, to complex systems with many layers of trees, shrubs, and herbaceous plants stacked together as appropriate for their needs. Examples of understory crops that can be integrated with forestry include trees crops like guava, along with pepper, ginger etc.

Silvo-pastoral systems: When planned properly, grazing livestock can be integrated with certain tree species. In this scenario, the livestock play two roles. First, the animals are a source of income. The grazing livestock provides biological control of weeds and brush with minimal use of herbicides or mowing. In silvopastural systems, the interactions among timber forage and livestock are managed intensively to simultaniously produce timber commodities, high quality forage and efficient livestock production. For silvopastoral systems, timber species are usually spaced wider than standard to optimize healthy pasture forage underneath. Potential livestock choices include cattle, sheep, goats and chickens.

Silvopasture can provide a relatively constant income from livestock sale. At the same time, the economic risk of the project is reduced because the system yields multiple products. Also, production costs are reduced by distributing management costs between timber and livestock components.

Multipurpose timber species: Some timber trees can provide secondary non-timber products. These can include seeds, fruits, essential oils, medicinal products, resins, flowers, and more. In some cases, harvest of these products can begin after only a few years, and may provide a steady income until the trees are harvested for their timber.

Examples of timber trees that have economically viable secondary products include neem (Azadirachta indica), with recognized medicinal and insecticidal properties in the leaf, seeds, and bark; jackfruit (Artocarpus heterophyllus), which produces fruit, dyes, and medicinal products; teak (Tectona grandis), with many traditional medicinal uses; and mango (Mangifera indica), valued for its fruit.

\section{Conclusion}

A relatively large percentage of the population in Bangladesh lives under the poverty line and is affected by the countries degrading natural resources. The present research assesses the contribution of tropical agroforestry to livelihoods in a rural area. Agroforestry systems are a land management technique that implies a combination of forest trees with crops. It has now earned a distinct identity as an approach to land use. Results indicate that agroforestry may not only be an optimal solution for poor farmers, species diversity conservation and environmental sustainability but may also have good economic rates of return. The study has led to the conclusion that agroforestry may be considered as one of the major strategies for poverty reduction in Bangladesh, where there is little scope of conserving forest due to the obvious priority for food crop production. Agroforestry not only helps to increase food and fodder but also protects the existing forest where unemployed and poor people rush to earn their livelihood. It is therefore, important that the policy makers, NGOs and Government Organizations should promote sustainable tropical agroforestry in developing environment-friendly and cost-effective technologies for poverty reduction in Bangladesh.

\section{REFERENCES}

Alim A (1980). Integrated rural development, protection of forest, use of forest soil potential and connection of rural poor to waste and marginal land. Institute of Forestry, Chittagong University, Bangladesh (Unpublished)

Asian Development Bank (ADB) (2004). Regional study on forest policy and institutional reform. Final Report of Bangladesh Case Study. Metro Manila, Philippines.

Asian Development Bank (ADB) (2001). Chittagong hill tracts region development plan. ADB TA No. 3328. Bangladesh.

Economic and Social Commission for Asia and the Pacific [ESCAP] (2009). 2009 ESCAP population data sheet. Population and Rural and Urban Development Division, Bangkok.

FAO (2009). State of the World's forests 2009. Rome, Italy.

Islam SS, Kibria MG, Chowdhury MH (1998). Financial analysis of agroforestry trial at Ichamati, Chittagong. Bang. J. For. Sci., 2(27): 46-54.

Nair PKR (ed.) (1989). Agroforestry systems in the tropics. Kluwer Academic Publishers and ICRAF, Dordrecht, The Netherlands.

Rahman SA, Rahman MF, Codilan AL, Farhana KM (2007). Analysis of the economic benefits from systematic improvements to shifting cultivation and its evolution towards stable continuous agroforestry in the upland of eastern Bangladesh. Int. For. Rev., 9(1): 536-547.

Rahman SA, Groot W de, Snelder DJ (2008). Exploring the agroforestry adoption gap: Financial and socioeconomics of litchi-based agroforestry by smallholders in Rajshahi (Bangladesh). In: Snelder DJ, Lasco RD (eds.), Smallholder tree growing for rural development and environmental services: Lessons from Asia. Springer, The Netherlands, pp. 227-244.

United Nations Development Programme [UNDP] (2009). Human Development Report 2009. New York.

World Bank (2000). World Development Report 2000. Oxford University Press, Oxford. 